\title{
Building of an Innovative Talent Development Model for Agricultural Colleges and Universities Yingjie $\mathrm{FU}^{1, \text { a }}$

\author{
aemail:jlaufyj@126.com
} \\ ${ }^{1}$ Department of Teaching Affairs, Jilin Agricultural University, 130118, Changchun, China
}

\begin{abstract}
Keywords: Agricultural colleges and universities; Talent development model; Innovative talent; Regional economy
\end{abstract}

\begin{abstract}
Establishment of a new talent development model is an important topic facing agricultural colleges and universities in the 21st century. Based on analysis of the significance of building an innovative talent development model for agricultural colleges and universities and problems with the current innovative talent model, countermeasures to build an innovative talent development model for agricultural colleges and universities are put forward.
\end{abstract}

\section{Introduction}

Higher agricultural education is a cradle to spread scientific knowledge of agriculture and to develop agricultural talents as well. Gradually, it has become a decisive factor of development of agricultural economy and a basic condition for all-around social development. In the current stage, it is imperative to keep on improving quality of higher agricultural education and to bring up creative, competitive and pioneering agricultural talents with all-around development intelligently, morally and physically and meeting development requirements of the new agricultural technological revolution and knowledge-based economy. In order to fulfil the historical mission, building of a brand-new innovative talent development model is the linchpin and basis.

In building the innovative talent development model, emphasis should be put on developing students' innovative spirit and ability. Higher agricultural education, in its essence, plays a dominant role in developing agricultural students' innovative spirit and ability. During the innovative talent development process, schools and educational administrative departments should immediately reflect on every link of their education, teaching and management. Consistent improvement of the talent development environment can integrate various environmental elements to serve development of innovative talents, comprehensively function on students' internal system and improve students' existing innovative spirit and ability. All these together can lay a solid foundation for development of pioneering and innovative agricultural talents.

\section{Significance of building an innovative talent development model}

Development of innovative talents is at the core of higher education in the new period. In response to China's initiative of building an innovative country, development of the knowledge-based economy and the popular development of China's higher education, colleges and universities must reform their innovative talent development model. In this way, they can guarantee full implementation of quality-oriented education, improvement of students' all-around development and development of students' innovative spirit and ability ${ }^{[1]}$. To realize the goal of talent development is of deciding significance to building of an innovative talent development model.

The talent development model is often restricted by social economy, politics, culture, educational concepts and other factors. Against the macroscopic background of building an innovative country, the previously traditional talent development model oriented towards knowledge and professionals has gradually shown its defects. Based on update of educational concepts, building of an innovative undergraduate development model has become an inevitable and practical choice of colleges and universities. Without exception, higher agricultural colleges and 
universities shall also undertake the historical mission of bringing up highly-qualified innovative talents to serve the building of an innovative country and the development of modern agricultural development ${ }^{[2]}$. Under the guidance of the scientific outlook on development, colleges and universities should upgrade their educational concepts, deepen their educational reform and build an innovative talent development model.

\section{Existing problems of China's current higher education talent development model reform}

Lack of active talent development model reform

Current talent development in China is not sensitive enough to social demands.Talent development model reform is often passive and targeted at adapting to social development. Despite of vigorous exploration efforts made by universities and colleges, some of them fail to accurately position their talent development model reform based on their campus conditions, regional development and national conditions; some of them just mend the current model or simply copy others' experiences; some even adopt a wait-and-see policy. Generally speaking, the current talent development model reform is less targeted and innovative.

Lack of systematic talent development model reform

The talent development model is a systematic whole constituted by interaction between several factors and the external environment. Therefore, the talent development model reform means not just changes of development plans, curriculum adjustment and introduction of foreign resources. More importantly, it means platform building and active response to outside changes. To be specific, it should include layout and positioning of subject construction, strategies and measures of curriculum construction, enhancement of management and quality assurance. In terms of practices, lack of systematicness is mainly reflected as lack of a systematic and comprehensive college and university reform, an overall planning and systematic design of talent development, andall-around interaction between development plans and conditions ${ }^{[3]}$.

Lack of time and space for students' personalized development

Talent development in China's colleges and universities often centers on teachers and administrators. Sometimes, it tends to be a preformed model and an enclosed model. A flexible learning system which allows students to decide has not yet been set up. In order to achieve personalized development of students, universities and colleges should realize diversity of students and build a diversified talent development model to meet students' diversified development demands.

\section{Countermeasures for the talent development model for local agricultural colleges and universities}

Reasonably position local agricultural colleges and universities in accordance with regional economic and social development

While clarifying school-running goals and positioning school-running directions, agricultural colleges and universities should consider internal and external school-running conditions, learn government's development planning, student talent demands and their changing trend and conduct full demonstration based on three elements (functions of colleges and universities, subjects and service objects) so as to make scientific decisions. Besides, they should do a good job in development planning and strategy selection, avoid weaknesses and enhance strengths, fully consider the local economic development status and the future development direction, pool in wisdoms and effectively improve their school-running level ${ }^{[4]}$. Only when local universities and colleges efficiently provide talents meeting development requirements of regional economic development and serve "agriculture, farmers and rural areas" can they acquire eternal creativity and vigor.

Implement the industry-study-research cooperation and innovate the school-running model of local agricultural colleges and universities

In formulating talent development plans, colleges and universities shall appropriately increase 
the percentage of experimental lessons to change their overemphasis on theories and ignorance of practices in the past. A technology-based teaching system should be put in place so as to achieve new breakthroughs for the talent development model. While implementing the talent development plans, colleges and universities should clarify their requirements, including building an interconnected, closely-related and organically-constituted curriculum system based on development goals, emphasizing on "refined and new teaching content", preventing overlapping of courses, enriching content of teaching links and teaching approaches, and finally forming a practical teaching system independent from theories but also closely connected with it. Besides, they should expose agricultural majors to a wide range of agricultural knowledge and practical skills so as to turn them into competitive talents in the job market. Construction and development of industry-university-research bases can provide bases for scientific research and practices of teachers and students; enhance students' practical abilities; contribute to strengthening students' understanding of professional knowledge; spark their interest in professional knowledge; and foster their scientific attitude and scientific research abilities.

Build a people-oriented contemporary university management system

Local agricultural colleges and universities regard students at the core of their survival, and development, employment and improvement of entrepreneurship skills of students as the foundation for their development. It is necessary for local higher agricultural colleges and universities to promote establishment of the modern university system with characteristics of higher agricultural colleges and universities. A relaxing learning environment can be created to respect students' personality and choices. In this way, every student can build their confidence and embark on the path of success. In terms of the curriculum system setting, more optional courses can be offered. By doing so, colleges and universities can expand students' knowledge range, expand their vision and improve their adaptability and innovative ability. Besides, greater importance should be attached to development of students' humanistic qualities and innovative abilities, improvement of school-running level of local agricultural colleges and universities, enrichment of their connotation and expansion of their educational activities.

Develop entrepreneurial talents

Development plan design should be targeted, applicable, practical and innovative. During the professional teaching process, the teaching content should be condensed to meet students'demands of becoming rich, putting their knowledge into practice and mastering skills. In terms of curriculum arrangement, the traditional agricultural courses should be reformed and the textbooks with characteristics of colleges and universities themselves should be compiled and cater to modernization and industrial development. In terms of teaching organization, attention should be paid to teaching effects. Colleges and universities should increase practices, and connect practical skills acquired by students with the local industrial development. In this way, university students can become leaders of creating wealth based on science and technology. During the teaching process, the " $2+2$ " training model meaning two years of basic theoretical knowledge and skill learning and two years of production practices to finish, can be implemented. The training model can expose students to a systematic range of practical skills and develop their innovative awareness and entrepreneurial abilities ${ }^{[5]}$.

Strengthen international cooperation and exchange

International cooperation and exchange as well internationalization of talent development is an indispensable part of talent development approaches, reform and innovation of colleges and universities. First, colleges and universities should actively and vigorously absorb excellent student source and enhance their competitiveness in the international arena. Second, a talent development model featuring collaboration of various colleges and universities should be explored. In particular, exchange programs can be held among colleges and universities aiming at bringing up advanced talents both at home and abroad. Third, internationalization of the teaching process and methods should be promoted. The original version of foreign textbooks can be introduced; bilingual even all-English teaching can be implemented; education for foreign students should be enhanced, and foreign experts can be employed to give lectures or teach specific courses; teachers can be sent 
abroad for further study and scientific research. All these efforts can be made to develop advanced talents with an international vision and international communication skills.

\section{Conclusion}

All in all, to make the goal of bringing up innovative talents real relies on innovation of the talent development model. To the end, the development model should be changed along with development objectives and conditions. Besides, higher agricultural colleges and universities should keep on developing and innovatingthe talent development model so as to realize the goal of developing innovative talents meeting development requirements of modern society.

\section{References}

[1] Zeng Linghui. Research on the cultivation mode of Applied Talents in university based on the excellent teaching perspective[J].Research in Higher Education of Engineering,2016(2).

[2] Liu Ying. On the reform of college talent training mode and its strategy[J].Heilongjiang Researches on Higher Education,2011(1).

[3] Lin Ling. Research on "talent training mode" in Colleges and Universities[J].Journal of Sichuan Normal University(Social Sciences Edition),2008(7).

[4] Ma Tingqi. Innovation personnel training and the reform of university personnel training mode[J]. Modern Education Science,2011(9).

[5] Zhang Wang. Realistic reflection and contemporary innovation of talent cultivation mode[J]. Educational Research,2015(1). 